\title{
Front Matter: Volume 8217
}

, "Front Matter: Volume 8217," Proc. SPIE 8217, Endoscopic Microscopy VII, 821701 (8 March 2012); doi: 10.1117/12.928775

SPIE. Event: SPIE BiOS, 2012, San Francisco, California, United States 


\title{
PROGRESS IN BIOMEDICAL OPTICS AND IMAGING
}

Vol. 13, No. 11

\section{Endoscopic Microscopy VII}

\author{
Guillermo J. Tearney \\ Thomas D. Wang \\ Editors
}

22-23 January 2012

San Francisco, California, United States

Sponsored and Published by

SPIE

Volume 8217 
The papers included in this volume were part of the technical conference cited on the cover and title page. Papers were selected and subject to review by the editors and conference program committee. Some conference presentations may not be available for publication. The papers published in these proceedings reflect the work and thoughts of the authors and are published herein as submitted. The publisher is not responsible for the validity of the information or for any outcomes resulting from reliance thereon.

Please use the following format to cite material from this book:

Author(s), "Title of Paper," in Endoscopic Microscopy VII, edited by Guillermo J. Tearney, Thomas D. Wang, Proceedings of SPIE Vol. 8217 (SPIE, Bellingham, WA, 2012) Article CID Number.

ISSN $1605-7422$

ISBN 9780819488602

Published by

SPIE

P.O. Box 10, Bellingham, Washington 98227-0010 USA

Telephone +1 3606763290 (Pacific Time) · Fax +1 3606471445

SPIE.org

Copyright (C) 2012, Society of Photo-Optical Instrumentation Engineers.

Copying of material in this book for internal or personal use, or for the internal or personal use of specific clients, beyond the fair use provisions granted by the U.S. Copyright Law is authorized by SPIE subject to payment of copying fees. The Transactional Reporting Service base fee for this volume is $\$ 18.00$ per article (or portion thereof), which should be paid directly to the Copyright Clearance Center (CCC), 222 Rosewood Drive, Danvers, MA 01923. Payment may also be made electronically through CCC Online at copyright.com. Other copying for republication, resale, advertising or promotion, or any form of systematic or multiple reproduction of any material in this book is prohibited except with permission in writing from the publisher. The CCC fee code is 1605$7422 / 12 / \$ 18.00$.

Printed in the United States of America.

Publication of record for individual papers is online in the SPIE Digital Library.

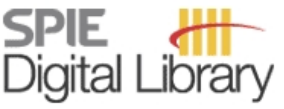

SPIEDigitalLibrary.org

Paper Numbering: Proceedings of SPIE follow an e-First publication model, with papers published first online and then in print and on CD-ROM. Papers are published as they are submitted and meet publication criteria. A unique, consistent, permanent citation identifier (CID) number is assigned to each article at the time of the first publication. Utilization of CIDs allows articles to be fully citable as soon as they are published online, and connects the same identifier to all online, print, and electronic versions of the publication. SPIE uses a six-digit CID article numbering system in which:

- The first four digits correspond to the SPIE volume number.

- The last two digits indicate publication order within the volume using a Base 36 numbering system employing both numerals and letters. These two-number sets start with 00, 01, 02, 03, 04, $05,06,07,08,09,0 A, 0 B \ldots$. 0Z, followed by 10-1Z, 20-2Z, etc.

The CID number appears on each page of the manuscript. The complete citation is used on the first page, and an abbreviated version on subsequent pages. Numbers in the index correspond to the last two digits of the six-digit CID number. 


\section{Contents}

$\checkmark$ Conference Committee

\section{NOVEL TECHNIQUES}

821703 Fluorescence-based surface magnifying chromoendoscopy and optical coherence tomography endoscope [8217-02]

R. A. Wall, J. K. Barton, The Univ. of Arizona (United States)

821704 Development of a widefield SERS imaging endoscope [8217-03]

P. Z. McVeigh, Univ. of Toronto (Canada); R. J. Mallia, I. Veilleux, Ontario Cancer Institute, Univ. Health Network (Canada); B. C. Wilson, Univ. of Toronto (Canada) and Ontario Cancer Institute, Univ. Health Network (Canada)

821706 Compact clinical high-NA multiphoton endoscopy [8217-05]

M. Weinigel, H. G. Breunig, P. Fischer, M. Kellner-Höfer, R. Bückle, JenLab GmbH (Germany);

K. König, JenLab GmbH (Germany) and Saarland Univ. (Germany)

\section{OCT I}

8217 OE Endoscopic spectral domain optical coherence tomography of murine colonic morphology to determine effectiveness of chemopreventive and chemotherapeutic agents in colorectal cancer [8217-13]

S. LeGendre-McGhee, P. F. S. Rice, The Univ. of Arizona (United States); R. A. Wall, College of Optical Sciences, Univ. of Arizona (United States); J. Klein, The Univ. of Arizona (United States); A. Luttman, College of Optical Sciences, Univ. of Arizona (United States); K. Sprute, E. Gerner, The Univ. of Arizona (United States); J. K. Barton, The Univ. of Arizona (United States) and College of Optical Sciences, Univ. of Arizona (United States)

\section{FLUORESCENCE IMAGING}

8217 OG Wide-field near-infrared fluorescence endoscope for real-time in vivo imaging [8217-15] Z. Liu, S. J. Miller, B. P. Joshi, T. D. Wang, Univ. of Michigan (United States)

8217 0J Targeted detection of murine colonic dysplasia in vivo with flexible multispectral scanning fiber endoscopy [8217-18]

B. P. Joshi, S. J. Miller, Univ. of Michigan (United States); C. Lee, Univ. of Washington (United States); A. Gustad, Univ. of Michigan (United States); E. J. Seibel, Univ. of Washington (United States); T. D. Wang, Univ. of Michigan (United States) 
OCT II

8217 OK Correction of astigmatism in endoscopic OCT for esophageal and coronary imaging [8217-19]

T. Wang, Erasmus MC (Netherlands); A. F. W. van der Steen, Erasmus MC (Netherlands) and Interuniversity Cardiology Institute of The Netherlands (Netherlands); G. van Soest, Erasmus $M C$ (Netherlands)

\section{CONFOCAL MICROSCOPY}

821700 Confocal microlaparoscope for imaging the fallopian tube [8217-23]

T.-Y. Wu, College of Optical Sciences, Univ. of Arizona (United States) and Univ. of Arizona (United States); R. Schafer, A. R. Rouse, Univ. of Arizona (United States); A. F. Gmitro, College of Optical Sciences, Univ. of Arizona (United States) and Univ. of Arizona (United States)

Author Index 


\title{
Conference Committee
}

\author{
Symposium Chairs \\ James G. Fujimoto, Massachusetts Institute of Technology \\ (United States) \\ R. Rox Anderson, Wellman Center for Photomedicine, Massachusetts \\ General Hospital, Harvard School of Medicine (United States)
}

Program Track Chairs

Taun Vo-Dinh, Duke University (United States)

Anita Mahadevan-Jansen, Vanderbilt University (United States)

\section{Conference Chairs}

Guillermo J. Tearney, Wellman Center for Photomedicine, Massachusetts General Hospital, Harvard School of Medicine (United States)

Thomas D. Wang, University of Michigan (United States)

\section{Program Committee}

David L. Dickensheets, Montana State University (United States)

Arthur F. Gmitro, The University of Arizona (United States)

Ralf Kiesslich, Johannes Gutenberg-Universität Mainz (Germany)

Francois Lacombe, Mauna Kea Technologies (France)

Stephen Lam, The BC Cancer Agency Research Center (Canada)

Hiroshi Mashimo, VA Boston Healthcare System (United States)

Kenzi Murakami, Olympus Corporation (Japan)

Norman S. Nishioka, Massachusetts General Hospital (United States)

Wibool Piyawattanametha, National Electronics and Computer Technology Center (Thailand)

Mark J. Schnitzer, Stanford University School of Medicine (United States)

Peter T. C. So, Massachusetts Institute of Technology (United States)

Melissa J. Suter, Massachusetts General Hospital (United States)

Session Chairs

1 Keynote Session

Thomas D. Wang, University of Michigan (United States)

2 Novel Techniques

Peter T. C. So, Massachusetts Institute of Technology (United States) 
3 Spectral Encoding

Dvir Yelin, Technion-Israel Institute of Technology (Israel)

4 OCTI

Linbo Liu, Massachusetts General Hospital (United States)

$5 \quad$ Fluorescence Imaging

Thomas D. Wang, University of Michigan (United States)

6 OCT II

Melissa J. Suter, Massachusetts General Hospital (United States)

7 Confocal Microscopy

Andrew R. Rouse, The University of Arizona (United States) 